\title{
EstateTip
}

\section{De uitkeringstest en de tegenstrijdigbelangregeling bij de bv.} De wetgever geeft duidelijkheid

Uitgangspunt van artikel 2:216 lid $1 \mathrm{BW}$ is dat de algemene vergadering van een bv bevoegd is tot bestemming van de winst die door de vaststelling van de jaarrekening is bepaald en tot vaststelling van uitkeringen, voor zover het eigen vermogen groter is dan de reserves die krachtens de wet of de statuten moeten worden aangehouden. In de statuten kunnen deze bevoegdheden worden beperkt of toegekend aan een ander orgaan.

Een besluit dat strekt tot uitkering heeft echter geen gevolgen zolang het bestuur geen goedkeuring heeft verleend en niet tot uitkering is overgegaan. Het bestuur weigert slechts de goedkeuring indien het weet of redelijkerwijs behoort te voorzien dat de vennootschap na de uitkering niet zal kunnen blijven voortgaan met het betalen van haar opeisbare schulden. De wil van het bestuur geeft de doorslag, zo lijkt het. Uit de memorie van antwoord (31058, p. 11-12) blijkt echter dat het bestuur eigenlijk niet zo veel te zeggen heeft.

'Het bestuur weigert slechts de goedkeuring indien het weet of redelijkerwijs behoort te voorzien dat de vennootschap na de uitkering niet zal kunnen blijven voortgaan met het betalen van haar opeisbare schulden. Met het woord "slechts" wordt tot uitdrukking gebracht dat het bestuur uitsluitend de goedkeuring mag weigeren, indien de daarna genoemde omstandigheid zich voordoet. Het bestuur heeft daarbuiten geen discretionaire bevoegdheid tot goedkeuring. Anders gezegd: indien het bestuur bijvoorbeeld van oordeel is dat een voorziening moet worden getroffen om toekomstige investeringen mogelijk te maken, is het niet bevoegd om zijn goedkeuring aan het besluit tot bestemming van de winst te onthouden, indien de vennootschap haar opeisbare schulden kan blijven betalen. Dit sluit aan bij het uitgangspunt dat de algemene vergadering bevoegd is om de bestemming van de winst te bepalen binnen de marges van de noodzakelijke schuldeisersbescherming.

Indien de vennootschap na een uitkering niet kan voortgaan met het betalen van haar opeisbare schulden, zijn de bestuurders die dat ten tijde van de uitkering wisten of redelijkerwijs behoorden te voorzien jegens de vennootschap (interne aansprakelijkheid) hoofdelijk verbonden voor het tekort dat door de uitkering is ontstaan doch maximaal tot het bedrag van de uitkering, met de wettelijke rente vanaf de dag van de uitkering.

Een belangrijke vraag in de praktijk is of bestuurders in dit kader een tegenstrijdig belang in de zin van de wettelijke tegenstrijdigbelangregeling kunnen hebben. Dit kan bijvoorbeeld aan de orde zijn bij de uitkering van een zogenoemd successiedividend, de winstuitkering na overlijden waarmee de erfbelasting kan worden betaald. In de literatuur is verdedigd 
dat bij bestuurders met aandelen in de bv, dit niet hoeft te betekenen dat er sprake is van tegenstrijdig belang bij besluitvorming over dividenduitkeringen, met name omdat het criterium in artikel 2:216 BW duidelijk afgebakend is. Hier wordt echter ook wel anders over gedacht. Kortom, onduidelijkheid troef.

Er is echter positief nieuws te melden. In de nota naar aanleiding van het verslag bij het wetsvoorstel bestuur en toezicht rechtspersonen (Kamerstukken II 2018/19, 34491, 6, p. 12) wordt opheldering gegeven. Ik laat de minister aan het woord:

'Ten aanzien van het tweede punt constateren de onderzoekers verdeeldheid in de literatuur over de vraag hoe de tegenstrijdigbelangregeling zich verhoudt met de goedkeuringsbevoegdheid van het bestuur bij uitkeringen aan aandeelhouders (artikel 2:216 lid 2), indien bestuurders zelf aandelen houden (paragraaf 5.2, p. 125). Vooropgesteld zij dat de enkele omstandigheid dat een bestuurder een persoonlijk (financieel) belang heeft, niet behoeft te leiden tot de kwalificatie van een tegenstrijdig belang. Er is pas sprake van een tegenstrijdig belang wanneer de belangen van de bestuurder niet (meer) parallel lopen met die van de vennootschap. Of er sprake is van tegenstrijdig belang, hangt af van de concrete omstandigheden van het geval (Kamerstukken I, vergaderjaar 2012/2013, 32 512, nr. C, p. 8). Op grond van artikel 2:216 lid 2 weigert het bestuur de goedkeuring aan het besluit van de algemene vergadering tot uitkering van de winst indien het weet of redelijkerwijs behoort te voorzien dat de vennootschap na de uitkering niet zal kunnen blijven voortgaan met het betalen van haar opeisbare schulden. Deze goedkeuringsbevoegdheid voor het bestuur beperkt de bevoegdheid van de algemene vergadering om de winst te bestemmen, teneinde het belang van de vennootschap te bewaken dat zij haar schulden kan blijven voldoen (vgl. Kamerstukken I, vergaderjaar 2011/2012, 31 058, nr. C, p. 11 e.v.). Met deze goedkeuringsbevoegdheid is de toepasselijkheid van de tegenstrijdigbelangregeling niet goed verenigbaar. Bij een besluit tot goedkeuring van een uitkering heeft het bestuur juist niet de mogelijkheid om (eventueel tegenstrijdige) belangen af te wegen. Het bestuur mag een voorgenomen uitkering slechts toetsen aan het wettelijk omlijnde criterium van artikel 2:216 lid 2. De tegenstrijdigbelangregeling is derhalve niet van toepassing bij artikel 2:216 lid 2.'

Kortom, de tegenstrijdigbelangregeling is niet van toepassing bij artikel 2:216 lid 2 BW. Bij een besluit tot goedkeuring van een uitkering heeft het bestuur namelijk niet de mogelijkheid om eventuele tegenstrijdige belangen af te wegen. Het bestuur mag een voorgenomen uitkering slechts toetsen aan het wettelijk omlijnde criterium van artikel 2:216 lid 2 BW.

En zo is er weer een puzzelstukje gelegd. Op naar het volgende.

Tot volgende week!

mr. H. Koster

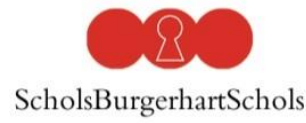

\section{Boomjuridisch}

$\underline{\text { www.scholsburgerhartschols.nl www.boomjuridisch.nl }}$ 